University of Nebraska - Lincoln

DigitalCommons@University of Nebraska - Lincoln

Faculty Publications: Materials Research

Science and Engineering Center

Materials Research Science and Engineering

Center

2005

Research Experiences for Teachers in Materials Science: A Case

Study

\author{
Michelle A. Strand \\ Southeast Community College- Milford, Milford, NE \\ Steve Wignall \\ Seward High School, Seward, NE \\ Diandra Leslie-Pelecky \\ University of Nebraska -- Lincoln, diandra2@unl.edu
}

Follow this and additional works at: https://digitalcommons.unl.edu/mrsecfacpubs

Part of the Materials Science and Engineering Commons

Strand, Michelle A.; Wignall, Steve; and Leslie-Pelecky, Diandra, "Research Experiences for Teachers in Materials Science: A Case Study" (2005). Faculty Publications: Materials Research Science and Engineering Center. 85.

https://digitalcommons.unl.edu/mrsecfacpubs/85

This Article is brought to you for free and open access by the Materials Research Science and Engineering Center at DigitalCommons@University of Nebraska - Lincoln. It has been accepted for inclusion in Faculty Publications: Materials Research Science and Engineering Center by an authorized administrator of DigitalCommons@University of Nebraska - Lincoln. 


\title{
Research Experiences for Teachers in Materials Science: A Case Study
}

\author{
Michelle A. Strand ${ }^{1}$, Steve Wignall ${ }^{2}$, and Diandra L. Leslie-Pelecky ${ }^{3}$ \\ ${ }^{1}$ Southeast Community College- Milford, Milford, NE 68405, U.S.A. \\ ${ }^{2}$ Seward High School, Seward NE 68434, U.S.A. \\ ${ }^{3}$ Department of Physics \& Astronomy and Center for Materials Research \& Analysis, University \\ of Nebraska - Lincoln, Lincoln NE 68588-0111, U.S.A.
}

\begin{abstract}
The National Science Education Standards encourage teachers to become involved in research as 'representatives of science in the classroom'. The Research Experiences for Teachers program affiliated with the Materials Research Science and Engineering Center at the University of Nebraska involves teachers in research on nanoscale magnetic and electronic structures over a summer. Two teachers and a sponsoring researcher share their experiences and what they believe are necessary elements for successful RET experiences.
\end{abstract}

\section{INTRODUCTION}

The National Science Education Standards suggest that teachers should be involved in scientific research as a component of their professional development: 'Teachers of science will be the representatives of the science community in their classes" [1]. This includes helping students learn that scientists may work alone or in teams, must develop good communication skills, and value reasoning, insight, energy, creativity, intellectual honesty, tolerance of ambiguity, skepticism and openness to new ideas [1]. First-hand participation in research can give teachers insight into the generation of new knowledge and strengthen content understanding. Educational research shows a direct relationship between teacher subject knowledge and student achievement [2]. The National Science Foundation, through its Research Experiences for Teachers (RET) program, has made it possible for many teachers to be involved in research, either with individual investigators, or as part of larger programs such as those hosted by Materials Science Research and Engineering Centers (MRSECs).

Much of the literature on teacher research experiences is descriptive [3, 4], although qualitative studies are beginning to appear [5]. Many sites have one or two teachers per year and no formal program affiliated with the research experiences. Longitudinal studies of larger programs are just beginning [6]. This paper presents the experiences of two high-school teachers and their research sponsor, and their perspectives on important elements for successful RET experiences. Themes that emerged from the surveys and discussions include: motivation for participating, expectations, becoming a contributing member of the group, and potential impact on students and research group members.

Q-SPINS (Quantum and Spin Phenomena in Nanomagnetic Structures) is the NSFsponsored MRSEC at the University of Nebraska - Lincoln. RET sponsorship is one part of the center's education/outreach activities. The RET program was advertised by sending a flyer to all high schools in Nebraska, all middle-level schools within a 90-minute drive, and via teacher workshops in which MRSEC faculty participated. Teachers selected for the program visited the university prior to the start of the program to interview prospective research sponsors. Matches were made by mutual consent of the teacher and the researcher. 


\section{RESULTS AND DISCUSSION}

\section{$\underline{\text { Motivation for participation }}$}

Michelle Strand, who participated in the program in Summer 2003, taught physics for 8 years at Pius X high school in Lincoln, a private Catholic school. Steve Wignall, who participated in Summer 2004, has been teaching for 23 years at Seward High School in Seward, NE (about 45 minutes from Lincoln). Both teachers were motivated to investigate the RET program by a desire to return to a college environment. Michelle noted that she didn't take the opportunity to participate in research as an undergraduate and felt like she missed out on something. Steve had prior research experience as an undergraduate and anticipated finding out what has changed since those experiences. Although both regularly attended summer professional development workshops focused on improving teaching, they were looking for 'something new' to do.

The research sponsor ran a REU program for six years and regularly worked with undergraduates; however, she had not involved teachers in her research group. She is the director of an NSF-sponsored Graduate K-12 program, which partners science graduate students with middle-level teachers, so she had significant previous experience working with teachers in the context of science education.

\section{$\underline{\text { Expectations }}$}

Since the research environment was an unknown, the teachers didn't have much of an idea what they would be expected to do or know prior to starting. Both teachers were intrigued by the interdisciplinary nature of the project: the development of a system for depositing magnetic nanoparticles into fluids. The resulting fluids have potential applications in drug delivery, hyperthermia and magnetic imaging. Michelle thought that she might be a 'worker bee', collecting data for already in-progress experiments. Regardless of the specific duties, both teachers were uncertain as to whether they had enough "physics knowledge" to contribute. It was important to both that they contribute, even if 'only in some small way' to the group. Michelle admits that she avoided physics as an undergraduate, even though she had dual majors in physical science and biology. A move and a new job...

“...thrust me into teaching physics and today, I wouldn't ever think about teaching anything but physics. But this lack of physics knowledge (I had been teaching myself what I was teaching the students), did leave me with a fear that I would look like an idiot when part of a research group."

The teacher's concern about lack of knowledge is mirrored in the uncertainty for the researchers as to what the teachers know. Teachers face significantly difference challenges and stand to gain in different ways - than participants in the related Research Experiences for Undergraduates (REU) programs. RET participants typically have more family and professional commitments, and may not be able to devote an entire summer to the program. Teachers have a much broader and varied skill set. 


\section{Research and the research group}

One advantage of the project on which both worked was that it represented a new line of inquiry for the lab: a departure for a traditional nanostructured materials researcher into the field of biomaterials. For Michelle, especially, this changed the nature of her participation. Although the system had been researched, designed, and partially built prior to her experience, the students working on the chamber were just starting to learn about the research field. The timing of her RET experience allowed her to learn along with the students. Even though the system was up and running when Steve arrived, there still were numerous issues of fixturing, optimizing deposition parameters, and understanding the materials that were fabricated.

From the researcher's perspective, this project presented two potential concerns: first that working on a piece of equipment was going to give the teachers a distorted view of what research was like, and second, that they wouldn't be learning much new physics due to the focus on getting equipment to work. On the other hand, custom design of equipment is an important part of nanostructured materials research. Michelle noted:

"I was slightly panicked when, on my first day I was asked to design a metal bath, a vital piece of equipment. Three weeks later, I had not only helped design the metal bath, but I had learned how to use the metal lathe and had fabricated it. A few other pieces were designed and made and right before my time was up, the chamber came together and we started the process of sealing it properly. I was shocked to see how much equipment has to be designed and made on site for each experiment."

Another element of research that researchers often overlook was noted by Michelle. "There was also a lot of waiting, something as a teacher I'm not too used to." Teachers often feel so pressured during the school year that they don't have as much time to reflect, research, and otherwise figure out how to incorporate content knowledge into their classes. The RET program allows them the luxury of reflection.

Steve had a slightly different challenge, as the equipment was starting to produce samples, but the group was still learning its capabilities. He had to catch up on the past year's experiences and worked closely with the postdoctoral researcher now leading the project. By the end of the summer, he was operating the deposition chamber by himself.

Both teachers commented that acceptance by the research group was important to them. As often happens, both teachers worked more with the students and the postdocs than with a faculty member.[5] Both teachers were surprised at the degree to which they were integrated into the group (i.e. attending group meetings, making posters for meetings, etc.) Other group members took the time to explain their research to the visiting teacher-scientists. "It felt wonderful to have been accepted into this great research group as a contributing member", Michelle said. Steve said, "He (the postdoc) explained every facet of the research to me and then listened to my ideas and thoughts about it. Several times he used our brain storming sessions to facilitate new ideas for our research project."

Both teachers made substantive contributions to the research group. They generated new ideas, such as how to modify the system design to enable collection of the fluid without having to open the system to air each time. They kept extremely thorough lab notebooks that have been a great help to other members of the group. Finally, they bring a different perspective to the lab and the students and postdocs viewed this as an opportunity to learn something new. 


\section{$\underline{\text { Impact }}$}

Both teachers have added papers and poster presentations to their resumes; however, the impact that shows up on paper is not as important as the impact on them personally. Both teachers felt they gained confidence in their ability to 'do physics' and appreciated being in the college-level environment. Steve said "It was such a breath of fresh air for me to be part of this atmosphere again".

One of the goals of RET program is to help teachers transmit information about the way science is done and current topics in science to their students. Although the impact on students may not show up for two-three years after the RET experience[6], both teachers indicate that the have used their experiences in their teaching.

"My students were able to hear how REAL research is done. I had never talked about it because I had no idea before this experience. With 95\% of my students going on to a four-year college, many of them may very well end up in this area of research and I felt I was now able to better prepare them. I was also able to give the students an idea of what kinds of cutting-edge research was being down right here in their hometown." (Michelle)

"My students are just starting to see some of the benefits of my RET. So far it has just been some of my experiences tied into my lectures and demonstrations, but eventually I would like to develop a unit on nanotechnology that I have the students do as part of the physics curriculum" (Steve)

The idea of getting into a new environment, on the 'cutting edge' of research was an important part of the teachers' motivation for applying, and both felt that the experience satisfied that desire. Steve, who had prior research experience as an undergraduate, said, "It was very rejuvenating for me as an educator to get back into the college setting again and be part of groundbreaking research in the nanotechnology area. I think every teacher should go back to this setting at least every 5 yrs to help keep them up on advancements and to fill their need for knowledge." Michelle decided, partially as a result of this experience, that she wanted to pursue a Masters degree in physics and is now also a graduate student.

The concern that working on a piece of equipment would limit the teachers' experience turned out to be unfounded, in part because of the teachers' integration into the group. Students and postdocs working on other projects also interacted with the teachers, often answering general questions or showing the teachers how to use various pieces of equipment. The teachers asked a lot of questions of all the research students, which provided the students experience explaining their research and gave the teachers a broader picture of the timescale on which research proceeds. The students benefited from having the teachers in the lab as well. In addition to helping them recognize how much they actually knew, they appreciated learning about the teachers' perspectives on education. 


\section{RECOMENDATIONS}

Although this paper is a snapshot of teacher experiences in materials science research, many of the themes identified are common to other programs [5]. The teachers and researchers identified three features critical to maintaining and improving the RET experience.

\section{Willing and able participants}

One of the most important components is having participants (teachers and research mentors) who are excited about participating. Teachers need to realize that this is a very different environment and be able to adapt. Michelle suggests that the most important quality a teacher should have is the willingness to ask a lot of questions. Similarly, faculty shouldn't be pressed into service. They should not be pressed into service unless they are committed to developing a project that can be done in the short time available. Since the faculty member usually spends the least time with the teacher, a suitable mentor must be identified from the members of the research group. The research group members must be willing to answer questions. Don't pair a teacher with a student trying to finish his thesis or one with minimal communication skills. Despite the fact that teachers will spend most of their time with students and postdocs, Michelle notes that the professor is probably the most intimidating person to the incoming teacher and needs to be aware of potential culture differences.

\section{$\underline{\text { Integration }}$}

It is critical that the teacher feels that he or she is a contributing member of the group. This is more than just making them feel welcome - it is making them feel useful. It is important for the faculty research sponsor to find an appropriate project. Development of apparatus was ideal for these teachers - there was something they could do immediately while they were learning about the physics that was to be done with the apparatus. Steve said, "I expected to be part of the research group, but not as deeply as it turned out. It was great to feel and be treated as an equal in the research I was involved in." A brand-new project can be risky if you end up waiting six weeks for a pump to arrive; however, it avoids the 'worker bee' situation where the teacher is a $\operatorname{cog}$ in a project already running full steam ahead. To some extent, understanding the 'big pictures' of the research process is more critical than specific science knowledge as the research process is the model for inquiry-based education.

\section{Making expectations clear}

Teachers rarely have prior experience they can use to anticipate what they will be expected to do or know. Research sponsors should clarify expectations at the very start. Although you can't predict where a project is going to go, an outline of what you hope can be accomplished, and a long-range explanation of the project is helpful to the teacher. The research sponsor needs to keep in mind that, unlike the REU program, the goal for the teachers is for them to translate their experience into their classrooms, not to get into graduate school. Clarify expectations about when you expect the teacher to be there prior to agreeing to work with her, and be prepared to be flexible when family commitments arise. Make sure the teachers know that they need to ask questions whenever they arise. 


\section{FUTURE DIRECTIONS}

One goal of this RET program is continuing the interaction between the research group and the teacher. This is difficult to do in practice give all of the other constraints of the school year. Giving teachers the opportunity to present their work - either the science or the RET experience - at local or national meetings provides an opportunity for greater interaction, as do projects that allow teachers to participate in consecutive years and that allot time during the summer specifically for developing materials for use during the school year. Our teachers have continued their relationships with the research group: they are included in group social events, Michelle presented her results at a MRSEC review, and Steve was a participant in a recent local biomagnetics conference. Both will present papers on their experiences at regional and local education and science conferences. Our future plans are to expand the RET collaborations to improve the transmission of information to high school students by developing materials that can be used by other teachers as well.

\section{CONCLUSIONS}

This experience allowed us to identify three primary elements - willingness, integration of the teacher into the research group, and providing the teachers with information and clear expectations - that form a necessary foundation for a valuable RET experience. The teacher who feels like an unwanted outsider doing busy work will not gain as much from the experience as the teacher who feel like she is an integral part of the research group. As more studies of RET experiences are published, it will be interesting to compare the effect of smaller programs with that of larger programs having a more formal structure.

\section{ACKNOWLEDGEMENTS}

This project was supported by the Nebraska Research Initiative and the MRSEC program of the National Science Foundation (DMR-0213808). We thank Jeffrey A. Shield, another RET research sponsor, for his comments on this manuscript.

\section{REFERENCES}

1. National Research Council, National Science Education Standards, (National Academy of Science, 1996)

2. B. Chaney, Student Outcomes and the Professional Preparation of Eighth-Grade Teachers in Science and Mathematics: NSF/NELS, (Westat, 1995).

3. R. L. Musselman, E. K. John, and G. W. Shaffer, J. Chem. Ed. 66, 653 (1989).

4. M. Johnson, The Science Teacher 69, 40 (2002).

5. F. Goodchild, C. Johnston, J. Mater. Educ. 23, 33 (2001).

6. J. Dubner, S. C. Silverstein, N. Carey, J. Frechtling, T. Busch-Johnsen, J. Han, G. Ordway, N. Hutchinson, J. Lanza, J. Winter, J. Miller, P. Ohme, J. Rayford, K. S. Weisbaum, K. Storm, and E. Zounar, J. Mater. Educ 23, 57 (2001). 